1 organising the inaugural ball for the ship's company at Christmas, so there is plenty to keep me busy out of surgery.

Life is certainly interesting onboard a warship. Whilst 'days off' don't exist at sea and the onset of clinical fatigue can be a risk, there are plenty of other things to drag you away from the dental chair and allow you to mix with the wider ship's company. This includes sport, very much encouraged onboard and easily organised with several large well-equipped gyms and a 4.5 acre flight deck. Whilst it has potential to feel claustrophobic, essentially living with your patients (and not having any windows), the ship is certainly large enough should you need to find a quiet corner. I have a particular nominated empty compartment where I disappear for a spot of yoga if occupational strains require release. The sense of camaraderie with colleagues is also very important and many feel almost like family when you spend so much time together and are 'all in the same boat', to excuse the terrible pun!

I have a few more months and some more sea-trials to undergo before I move on from this role. I hope I will leave a legacy of a functioning dental department and at least some 'Operating Procedures' for my various roles that make sense to my successor. I am very aware that I will look back at this as being a true highlight of my career. Certainly it has been everything that my 22-year-old self hoped for when a smartly dressed Naval Officer delivered a recruitment lecture over a lunch at university. I was hooked then, and now feel a great deal of pride that I have reached where I am today.

The BDA is looking for dentists to submit their stories for their 'We are dentistry' campaign. To tell your story please visit https://www. bda.org/wearedentistry.

\title{
Help ease festive hardship among dentists and their families
}

Christmas is an extra reminder of what life can bring - good or bad. The BDA Benevolent Fund is asking you to spare a thought for those within the profession who are struggling this festive season. Dentists aren't immune to bad luck and circumstances can change very quickly.

Professor Ros Keeton, Chair of the BDA Benevolent Fund, said: 'We recently supported a middle-aged dentist who had been a highly successful associate. Like many, he took the next step and purchased his own practice. Sadly, for a variety of reasons, it didn't work out as expected and he ran into significant debt. He was horrified to find himself in such a situation. He just didn't think this was something that would happen to him. Thankfully, someone suggested he contact the BDA Benevolent Fund and we were able to provide financial support to help with his living costs, weekly food bills and the mortgage - while he sorted out his business. He returned to working as an associate and hasn't looked back since.

'Physical or mental illness, accident, divorce and family bereavement can all change a person's life suddenly, and some people will find themselves unable to work in the short or long-term.

'Over the festive period, we get more requests, and we give out additional grants. We want dentists to feel a sense of normalcy and know that the profession is there to support them. We do not want children to miss out on Christmas presents, or for someone to spend New Year's Eve alone because they cannot afford to travel to spend time with their family.

The BDA Benevolent Fund aims to help dentists resolve their financial difficulties by getting back to work, either in dentistry or with a new opportunity.

Professor Keeton said: 'Short-term support like this is important to help people retain their dignity but, of course, our purpose is much longer term. Work provides a sense of well-being as well as the obvious aim of generating an income?

The charity also supports dental students and recently qualified professionals.

'Some young people have no family support and come from deprived backgrounds. They're assisted with student loans and bursaries and they work part-time, but sometimes this just isn't enough to live on.'

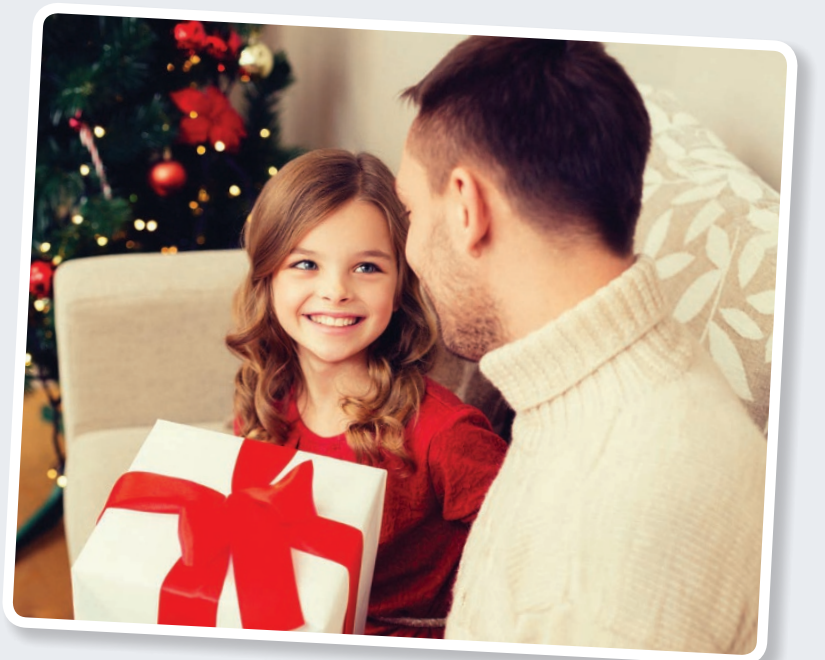

In the last few weeks of the summer, the BDA

Benevolent Fund helped two students who had difficulty securing accommodation, as it was impossible for them to raise the deposit often the equivalent of four or six weeks' worth of rent. The charity helped by giving them the means to secure somewhere to live. Without this, they planned to sleep in the library, hoping to remain unnoticed.

They can now focus on their studies, get their degree and be set for life.

If you, or anyone you know within dentistry, are dealing with financial difficulties, please do not hesitate to contact the BDA Benevolent Fund. All contact is confidential and if the charity can help, it will. If not, it will try to point you in the right direction.

The BDA Benevolent Fund would like to wish you well, and extend its thanks for your support and generosity throughout the year. Every $£ 1$ donated goes directly to a dentist and their family in crisis, so your help really does support someone in need.

To donate, please visit www.justgiving.com/bdabenevolentfund and contribute online or send a cheque payable to 'BDA Benevolent Fund, at BDA Benevolent Fund, 64 Wimpole Street, London, W1G 8 YS. If you are UK taxpayer, a further $25 \%$ of the value of your donation can be claimed from the government, so please be sure to complete a Gift Aid form.

For more information visit www.bdabenevolentfund.org.uk. 